\title{
Analisis Performa Modul Surya Cell Terhadap Penggunaan Reflektor Alumunium Foil
}

\author{
Joko Setiyono $^{\text {1a) }}$, Riyan Pramadi $^{1}$, Sulanjari ${ }^{1}$, dan Fifit Astuti ${ }^{1}$ \\ ${ }^{1}$ Universitas Pamulang, Jl. Surya Kencana No.1 Pamulang Barat, Kec. Pamulang, Kota Tangerang Selatan \\ 15417, Indonesia \\ E-mail: ${ }^{a)}$ dosen00889@unpam.ac.id
}

Received: 7 Agustus 2021 Revision: 1 September 2021 Accepted: 8 Oktober 2021

\begin{abstract}
Abstrak: Modul sel surya merupakan perangkat yang dapat mengubah sinar matahari menjadi energi listrik. Sinar matahari merupakan sumber energi terbarukan yang dapat digunakan sebagai pembangkit listrik baru. Namun dalam pengerjaannya sesuai dengan permintaan penambahan modul solar cell tertentu agar daya keluaran yang dihasilkan dapat optimal. Penelitian ini bertujuan untuk mengetahui pengaruh penambahan reflektor terhadap intensiatas, daya masukan dan daya keluaran modul sel surya yang dihasilkan, serta mengetahui efisiensi dari variasi kemiringan sudut reflektor. Modul solar cell yang digunakan adalah 1 unit dengan kapasitas $50 \mathrm{Wp}$. Pengujian dilakukan pada pukul 10.00-14.00, dengan menggnakan 2 dan 4 reflektor. Penelitian ini menggunakan reflektor dengan kemiringan $45^{\circ}$, 55, dan $65^{\circ}$ dengan tinggi reflektor $250 \mathrm{~mm}$ pada setiap sisinya. Daya keluaran modul sel surya menggunakan reflektor tertinggi adalah 65.737 Watt dengan sudut kemiringan $65^{\circ}$.
\end{abstract}

Kata Kunci: solar cell, reflector, daya masukan, daya keluaran dan efisiensi

\begin{abstract}
Solar cell module is a device that can convert sunlight into electrical energy. Sunlight is a renewable energy source that can be used as a new power plant. However, the process is in accordance with the request for the addition of certain solar cell modules so that the output power produced can be optimal. This study aims to determine the effect of adding a reflector to the intensity, input power and output power of the resulting solar cell module, and to determine the efficiency of the variation of the reflector angle. The solar cell module used is 1 unit with a capacity of $50 \mathrm{Wp}$. Tests were carried out at 10.00-14.00, using 2 and 4 reflectors. This study uses reflectors with a slope of $45^{\circ}, 55$, and $65^{\circ}$ with a reflector height of $250 \mathrm{~mm}$ on each side. The output power of the solar cell module using the highest reflector is 65,737 Watt with a tilt angle of $65^{\circ}$.
\end{abstract}

Keywords: solar cell, reflector, Input power, output power and efisiensi

\section{PENDAHULUAN}

Indonesia adalah negara dengan garis khatulistiwa yang memisahkan bumi menjadi 2 bagian yaitu utara dan selatan. Letak indonesia menyebabkan iklim yang dimiliki cerah hampir disepanjang tahun. Pada gambaran peta insolasi bertenaga matahari, Indonesia memiliki gaya radiasi berbasis sinar matahari setiap hari sebesar 4,8 $\mathrm{kW} / \mathrm{m} 2[1][2]$.

Kebutuhan energi listrik dari waktu ke waktu berkembang seiring dengan bertambahnya kebutuhan manusia saat melakukan aktivitasnya setiap hari. Pemanfaatan energi saat ini masih tergantung pada bahan bakar minyak. Energi matahari merupakan energi terbarukan yang potensial yang dapat dikembangkan sebagai sumber energi ini relatif murah dan melimpah, khususnya Indonesia sebagai negara yang memiliki panas dan kelembapan [3][4]. Energi berbasis sinar matahari merupakan energi yang tidak dapat dikonsumsi, dan tidak menimbulkan pencemaran sehingga energi yang berorientasi pada matahari dapat dimanfaatkan sebagai pengganti produk minyak bumi serta salah satu sumber daya berkelanjutan yang kemajuannya berkembang setiap tahun [2]. 
Pengisi daya bertenaga sinar matahari bekerja pada standar fotovoltaik. Photovoltaic sendiri merupakan suatu bahan atau gadget yang dapat mengubah energi foton secara lebih terang menjadi tegangan dan aliran listrik. Pada premis ini, sangat baik dapat dilihat bahwa presentasi pengisi daya berbasis sinar matahari sangat tunduk pada kekuatan radiasi berorientasi matahari yang didapat oleh permukaan. Ulasan ini akan mencoba membangun nilai ini dengan menerapkan reflektor bertenaga matahari empat sisi. Memperluas nilai gaya radiasi yang didapat akan membangun gaya luluh dan produktivitas pengisi daya bertenaga sinar matahari yang digunakan [5].

Dari penelitian sebelumnya, khususnya pemanfaatan reflektor cermin level sebagai penangkap matahari telah memberikan perkembangan baru, untuk meningkatkan pengisi daya bertenaga sinar matahari jika dibandingkan dengan penggunaan solar cell tanpa reflektor matahari [6]. Dan terbukti dengan meningkatnya nilai efektivitas yang dihasilkan. Meskipun demikian, penggunaan reflektor cermin tingkat dalam ulasan ini masih memiliki kelemahan pada penggunaannya. Oleh karena itu, pada penelitian ini akan digunakan reflektor sebagai alat penyaringan reflektor untuk mengenali titik pencahayaan terbesar secara lebih tepat. Dengan memvariasi penggunaan reflektorserta sudut reflektorterhadap solar cell.

\section{METODOLOGI}

Pada penelitian ini solar cell saat pengecasan aki yang di setiap sisinya diberi reflektor berbahan alumunium foil setinggi $250 \mathrm{~mm}$. Kemudian solar cell diuji dengan diberikan panas matahari dengan intensitas matahari yang berbeda-beda dalam waktu mulai jam 10:00 s/d 14:00 wib dengan melakukan Pengukuran tanpa reflektor. Reflektoryang diberikan pada desain solar cell divariasikan dengan 2 dan 4 reflektor. Setelah itu, sudut reflektor divariasikan pada sudut $45^{\circ}, 55^{\circ}$, dan sudut $65^{\circ}$. Lalu dilakukan pengukuran intensitas cahaya dan temperatur pada solar cell per 30 menit.

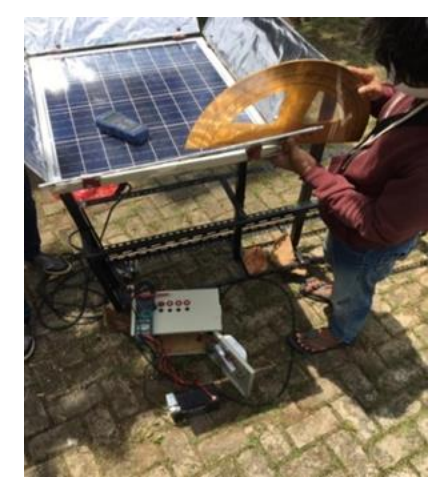

Gambar 1. Rancang bangun solar cell dengan tambagan 4 reflektor

\section{HASIL DAN PEMBAHASAN}

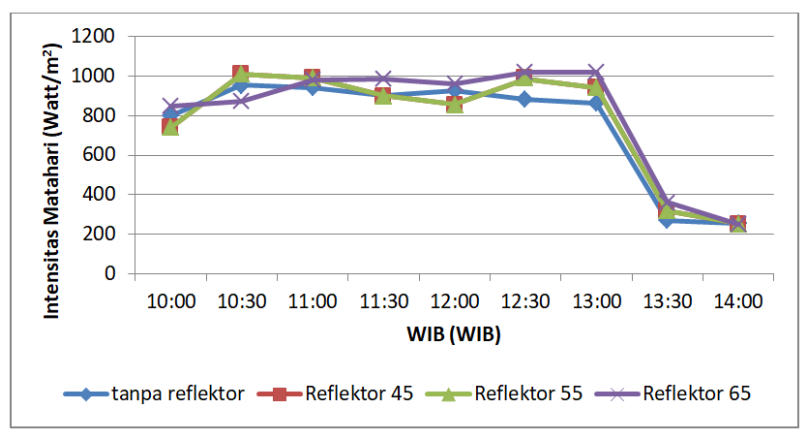

$\mathbf{a}$

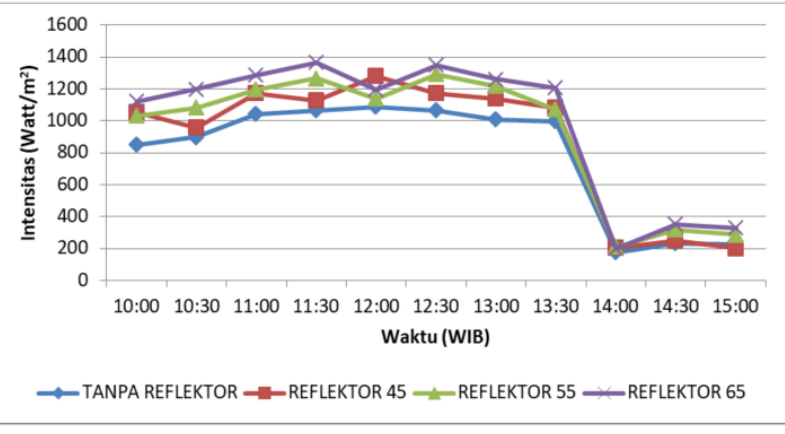

b 


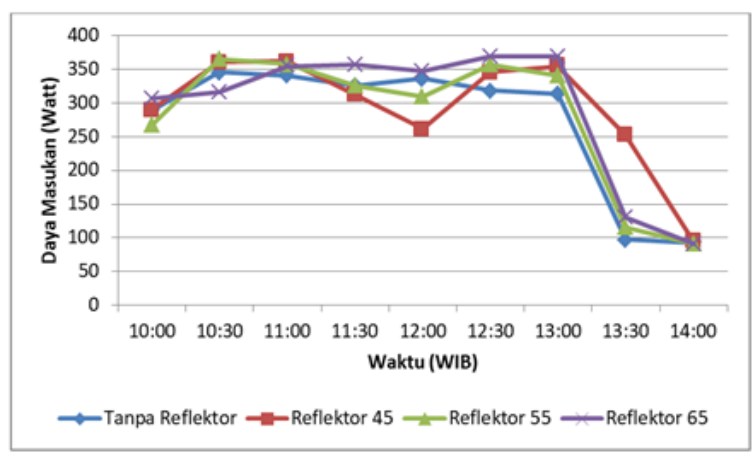

C

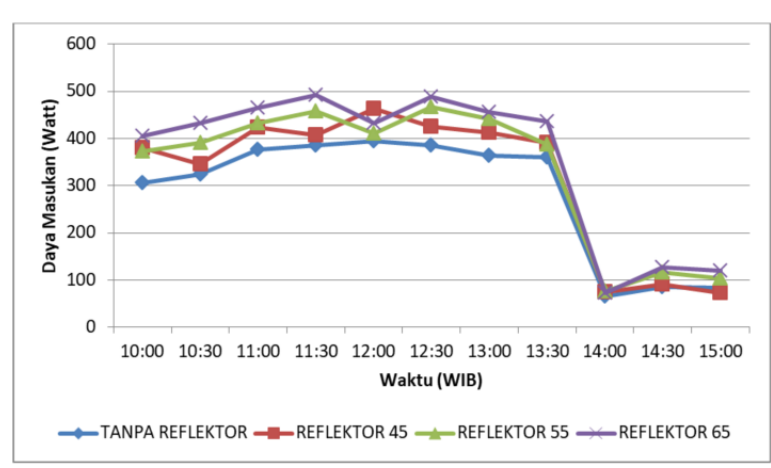

d

Gambar 2. Intensitas cahaya matahari terhadap waktu pada solar cell dengan a) 2 reflektor, b) 4 reflektor, serta daya masukan terhadap waktu pada solar cell dengan c) 2 reflektor, d) 4 reflektor

Berdasarkan gambar grafik 2a. dimana solar cell menggunakan 2 reflektor memiliki intensitas cahaya matahari dengan nilai tertinggi sebesar $1020 \mathrm{~W} / \mathrm{m}^{2}$ pada jam 13:00 WIB kemiringan reflektor65 ${ }^{\circ}$. Sedangkan pada grafik 2 b. dimana solar cell menggunakan 4 reflektor menghasilkan intensitas cahaya paling tinggi sekitar $1363 \mathrm{~W} / \mathrm{m}^{2}$ pada jam $11.00 \mathrm{WIB}$. Hal ini diakibatkan bahwa peggunaan reflektordengan menggunakan 4 reflektor lebih maksimal dalam memfokuskan cahaya matahari yang akan mengenai solar cell. Sehingga terjadi peningkatan yang signifikan pada nilai intensitas cahaya matahari yang tertangkap. Fenomena ini juga diperoleh oleh Sugeng (2021), dimana pada pengujian solar cell menggunakan reflektordiperoleh hasil maksimal saat mendekati pukul 11.00-13.00, dimana matahari mendekati posisi sejajar tepat diatas soalr cell [4].

Daya masukan terbesar didapat dengan besar daya masukan sebesar 369,036 Watt pada jam 13:00 WIB kemiringan reflektor $65^{\circ}$ merupakan nilai intensitas tertinggi pada solar cell dengan 2 reflektor. Sedangkan nilai intensitas tertinggi pada solar cell dengan 4 reflektor mencapai 496 Watt pada sudut reflektor $65^{\circ}$. Hal ini sesuai dengan penelitian oleh Reynaldo (2016), bahwa penggunaan reflektordengan sudut $65^{\circ}$ merupakan posisi terbaik dengan menghasilkan tegangan paling tinggi sebesar 20,6 V.

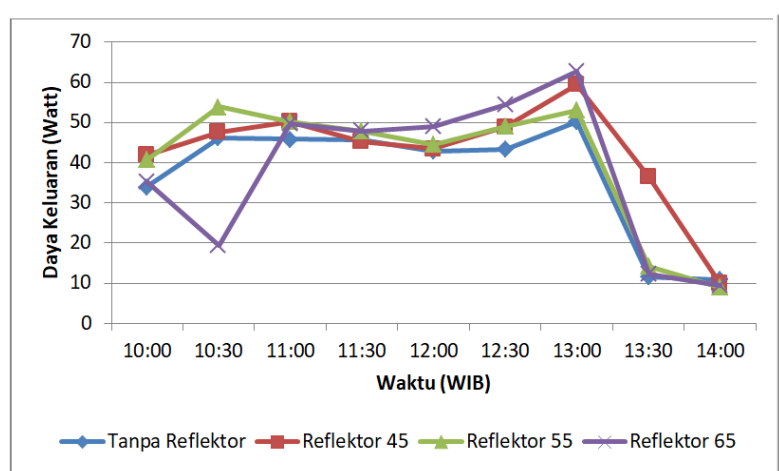

a

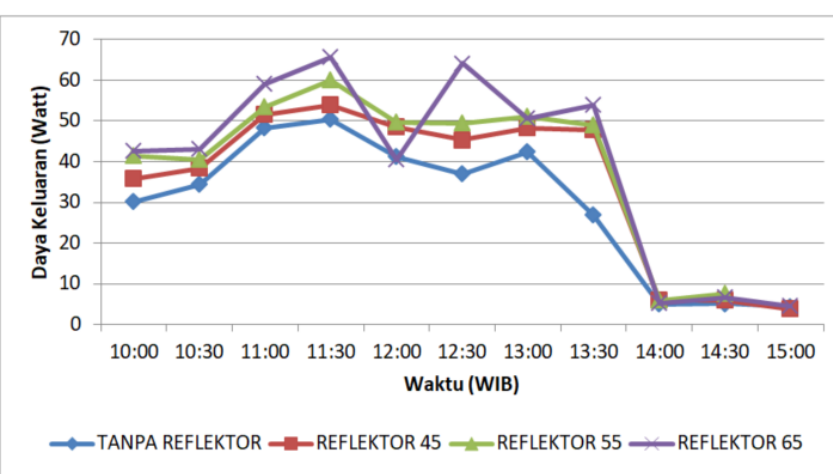

b

Gambar 3. Grafik daya keluaran terhadap waktu pada solar cell dengan a) 2 reflektor, b) 4 reflektor

Dari grafik 3a. terlihat daya keluaran terbesar didapat dengan besar daya keluran sebesar 62,829 Watt pada jam 13:00 WIB kemiringan reflektor65 $5^{\circ}$ saat solar cell menggunakan 2 reflector. sedangkan pada saat menggunakan 4 reflector, solar cell menghasilkan daya luaran mencapai 65,737 watt pada pukul 11.30 WIB dengan sudut $65^{\circ}$. 


\section{KESIMPULAN}

Dari penelitian yang telah dilakukan pada percobaan pada solar cell yang di jemur mulai pukul 10:00 s/d 15:00 dengan membandingkan penggunaan reflektorsebanyak 2 dan 4 buah reflector. Sudut kemiringan reflektordivariasi dengan sudut $45^{\circ}, 55^{\circ}, 65^{\circ}$. Hasil yang diperoleh menunjukkan bahwa penggunaan 4 reflektor lebih besar dalam menghasilkan intensitas, daya masukan serta daya keluaran. Hasil optimum didapatkan pada penggunaan 4 reflektor dengan sudut kemiringan $65^{\circ}$ dengan nilai intensitas sebesar $1363 \mathrm{~W} / \mathrm{m}^{2}$, daya masukan 496 Watt dan daya keluaran 65,737 watt.

\section{DAFTAR PUSTAKA}

[1] S. Aryza, P. Ehkan, W. Khairunizam, and Z. Lubis, "Implementasi Teknologi Greenpeace di Pembangkit Energy Solar Cell pada Daerah Minim Cahaya,” SEMNASTEK UISU 2019, pp. 1-4, 2019, [Online]. Available: jurnal.uisu.ac.id.

[2] P. K. Tiyas and M. Widyartono, "PENGARUH EFEK SUHU TERHADAP KINERJA PANEL SURYA," J. Tek. Elektro, vol. 1, no. 2020, pp. 871-876, 9AD.

[3] B. W. Nuryadin, A. Y. Nuryantini, and M. A. Ramdhani, "A solar simulator using a LCD projector for students' laboratory,” in Physics Education, 2018, vol. 53, no. 5, pp. 1-11, doi: 10.1088/1361-6552/aad4c2.

[4] S. Hariyanto, "Rancang Bangun REFLEKTORUntuk Mengoptimalkan Daya Serap Matahari Pada Panel Surya Dengan Variasi Sudut Guna Menghasilkan Daya Optimal," J. Ilm. TELSINAS, vol. 4, no. 1, pp. 41-45, 2021.

[5] R. H. A. Prastica, "Analisis Pengaruh Penambahan ReflektorTerhadap Tegangan Keluaran Modul Solar Cell," Universitas Muhammadiyah Surakarta, 2016.

[6] I. B. kd S. Negara, I. W. A. Wijaya, and A. A. G. M. Pemayun, "ANALISIS PERBANDINGAN OUTPUT DAYA LISTRIK PANEL SURYA SISTEM TRACKING DENGAN SOLAR REFLECTOR,” E-Journal SPEKTRUM, vol. 3, no. 1, pp. 7-13, 2016. 